\title{
2006-2486: IMPROVING ENGINEERING UNDERGRADUATE RETENTION VIA RESEARCH AND INTERNSHIPS
}

\section{Melinda Seevers, Boise State University}

Melinda Seevers is the Engineering Co-op Coordinator for the College of Engineering at Boise

State University. She develops and coordinates internships for lower and upper division undergraduates. She earned a B.S. degree in Mechanical Engineering from Cal Poly Pomona and has worked professionally in the aerospace and aviation industries.

\section{William Knowlton, Boise State University}

William B. Knowlton is an Associate Professor of Electrical and Computer Engineering at Boise State University. He has co-developed five new programs and a department in Materials Science and Engineering where he is the Coordinator for Graduate Studies and holds a joint appointment. His research activities include device and simple circuit reliability physics, materials characterization, nanofabrication of materials and devices, biomaterials, and molecular electronic devices. He is actively involved in integrating teaching and research has received several teaching and research awards.

\section{Pat Pyke, Boise State University}

Patricia Pyke is the Director of Special Programs for the College of Engineering at Boise State University. She oversees projects in freshman curriculum development, retention, math support, mentoring, and women's programs. She earned a B.S.E. degree in Mechanical Engineering from Duke University and a Master's degree in journalism from the University of California at Berkeley.

\section{Cheryl Schrader, Boise State University}

Cheryl B. Schrader is Dean of the College of Engineering and Professor of Electrical and Computer Engineering at Boise State University. Dean Schrader has an extensive record of publications and sponsored research in the systems, control and engineering education fields. She recently received the Presidential Award for Excellence in Science, Mathematics and Engineering Mentoring from the White House for an enduring, strong, and personal commitment to underrepresented engineering students and faculty.

\section{John Gardner, Boise State University}

John F. Gardner is Chair of the Mechanical Engineering Department at Boise State University. He is also Director of the Hewlett Foundation funded Engineering Schools of the West Intiative at Boise State. His current research interests, in addition to engineering education, include dynamic systems and sustainable energy systems. 


\title{
Improving Engineering Undergraduate Retention via Research and Internships
}

\begin{abstract}
Retention of lower division students is a continuing concern in academia. In response to these concerns, a program was initiated in the Boise State University College of Engineering to improve lower division retention via research and internships. Inclusion of lower division students in both university research and industry internships is contrary to prevailing perceptions of student capabilities. However, lower division engineering students generally possess numerous basic skills that enable them to work in an engineering environment where they can gain experience and confidence. Phase One of the Retention through Research and Internships Program was a pilot program in which seven first year engineering students were placed in research laboratories with faculty mentors within the College of Engineering during the 2004-05 academic year. At the beginning of the Fall 2005 semester, 100\% of the participating students remained in the program. In addition, interviews of the students revealed that many believed that the research laboratory experience and environment increased their confidence and motivation, and was pivotal in their decision to remain in engineering. As a result of the successful Phase One pilot program, a Phase Two program has been initiated, in which first and second year engineering students are being placed in industry internships during the academic year 2005-06.
\end{abstract}

\section{Introduction}

Student retention is an issue among university academic programs nationwide; however, in a field already plagued with declining enrollment, retaining engineering students is of particular importance. Boise State University students that did not return for their second year were interviewed by the Office of Institutional Assessment. Financial difficulties were given as the most common reason for not returning the following semester. Of those surveyed, $21 \%$ stated finances were the major factor, and $16 \%$ left primarily due to job responsibilities. Other reasons included lack of motivation and feeling alone and isolated. ${ }^{1}$ As one of the nine western engineering colleges engaging in the William and Flora Hewlett Foundation Engineering Schools of the West Initiative, the Boise State University College of Engineering received a fiveyear grant to support recruitment and retention programs. To address the concerns of students leaving due to financial difficulties and lack of engagement, a pilot program (Phase One) was launched in 2004 funded by this grant.

Internships, either in research or industry, allow students to connect theory to practice through work-based, experiential learning. Participation in an internship allows students to receive mentoring from role models working in the engineering research lab or industry, and from fellow interns in an organization. Prior research has shown that students engaged in undergraduate research perceived a positive impact on their cognitive and personal skills, and that students were more likely to pursue graduate degrees. ${ }^{2}$ Additionally, significant positive effects from student participation in cooperative education upon academic performance and graduate earnings have been statistically reported. ${ }^{3}$ Based on this data, pilot programs were initiated to increase retention 
rates of lower division engineering students by providing them with internship opportunities both within the college research laboratories and in industry.

\section{Pilot Program}

During the 2004-05 academic year the Retention through Research and Internships Program was launched by the authors with the placement of seven first year engineering students within the College of Engineering research laboratories. Introducing freshman engineering students to research would potentially create an atmosphere of excitement, teamwork and inclusiveness to encourage them to continue their engineering studies. All freshman engineering students who had successfully passed the Introduction to Engineering course, ENGR 120, were eligible. Prerequisites for this course are Precalculus, or College Algebra and Analytic Geometry. Underrepresented groups were especially encouraged to participate, including women, African Americans, Hispanics, and non-traditional students (students age 25 or older). The latter group is often ignored by other retention programs, yet this group faces very specific challenges in attaining an engineering degree. Non-traditional students are highly motivated and represent a rich resource to help meet the demand for engineers in the workforce. However, this group is particularly susceptible to high drop-out rates in engineering programs due to competing responsibilities including family and financial needs. ${ }^{4}$

Students were selected for the pilot program based on recommendation from a faculty member teaching ENGR 120. In order to provide the nurturing environment to help sustain freshman engineering students through their first academic year, research students and professors were carefully selected. The goal was to place five to eight students per year.

During the 2004-05 academic year, seven freshman students were placed in research positions within the College of Engineering through the program. The research assistantships were funded by the Hewlett grant. Students came from a variety and combination of backgrounds which represent groups known to face greater challenges in completing an engineering curriculum. Research assistant backgrounds and laboratories are shown in Table 1.

\begin{tabular}{|c|c|l|c|c|c|c|}
\hline $\begin{array}{c}\text { Research } \\
\text { Assistant }\end{array}$ & Major & \multicolumn{1}{|c|}{ Laboratory } & $\begin{array}{c}\text { Non- } \\
\text { traditional }\end{array}$ & $\begin{array}{c}\text { Hispanic } \\
\text { or other } \\
\text { Minority }\end{array}$ & Female & $\begin{array}{c}\text { First } \\
\text { Generation } \\
\text { College } \\
\text { Student }\end{array}$ \\
\hline 1 & EE & $\begin{array}{l}\text { Device and IC } \\
\text { Characterization }\end{array}$ & $\mathrm{X}$ & $\mathrm{X}$ & & $\mathrm{X}$ \\
\hline 2 & $\mathrm{EE} / \mathrm{CS}$ & $\begin{array}{l}\text { Digital Systems and } \\
\text { Design }\end{array}$ & $\mathrm{X}$ & & & \\
\hline 3 & $\mathrm{CE}$ & Biomechanics & & & $\mathrm{X}$ & $\mathrm{X}$ \\
\hline 4 & $\mathrm{CE}$ & $\begin{array}{l}\text { Environmental } \\
\text { Sensing }\end{array}$ & $\mathrm{X}$ & & $\mathrm{X}$ & \\
\hline 5 & $\mathrm{CE}$ & Soils & & & & $\mathrm{X}$ \\
\hline 6 & $\mathrm{EE}$ & Signal Processing & & $\mathrm{X}$ & & $\mathrm{X}$ \\
\hline 7 & $\mathrm{EE}$ & Mechatronics & & $\mathrm{X}$ & & \\
\hline
\end{tabular}

Table 1. Backgrounds and placement of freshman research assistants during Phase One. 
Post-year interview surveys were filled out by all research assistants at the end of the 2004-05 academic year. Interviews revealed that students garnered mentoring and a sense of community from working alongside upper division students, graduate students and faculty researchers. Students also expressed increased understanding of coursework, confidence and motivation gained from hands-on research laboratory accomplishments. Most notable was that the experience was pivotal for some students in their decision to remain in engineering. At the end of year $1,100 \%$ retention was achieved as measured by all participating student researchers returning to enroll in engineering the Fall 2005 semester.

\section{Year 2: Lower Division Research Students}

During the summer of 2005, funds were shifted to other recruitment and retention programs supported by the Hewlett grant including the hiring of a professional staff person with an engineering background to take the research assistantship and internship program to the next level and provide additional mentoring support to students. No additional research assistantships were funded via the Hewlett grant. However, with the successful placement of seven first-year students, the stage was set for research faculty to continue hiring the same students for their second year and/or to hire on new first-year students. During the 2005-06 academic year, four freshmen were hired as research assistants; two funded by research grants, and two funded by Federal Work-Study. In support of including more undergraduates in research, our college business manager successfully obtained a significant increase in Work-Study allocation. Of the original seven Hewlett funded students, four 'graduated' to be hired on funded research by their faculty mentors for their second year of studies, one was not re-hired for the Fall semester but remained enrolled as a student, one continued working in the lab with Hewlett funding, and one was hired in the fall for an industry internship via the new industry internship for lower division students program. As of early 2006, 13 lower division students are working in College of Engineering research laboratories.

\section{Phase 2: Industry Internships}

As a result of the successful pilot program placing lower division students in labs, Phase Two was begun, in which first and second year engineering students are being placed in industry internships during the academic year 2005-06. First or second year students (or freshman/sophomore) are defined by their standing within their engineering major. Establishing a lower division internship program poses several challenges. When companies seek internship students, they traditionally request junior or senior students because they are more academically advanced. Likewise, lower division students do not typically consider themselves eligible or qualified to work as industry interns.

A two-fold approach was taken to implement the program; identify companies potentially willing to employ lower division students, and locate student candidates. To expand opportunities for lower division students, companies were contacted both by letter and phone. Emphasis was placed on companies that employ engineers and that were within commuting distance to the campus. Companies fell into three categories; those which have hired our students both as graduates and interns, those which have hired graduates but never an intern, and those which 
have no previous hiring relationship with the College of Engineering. Beginning in the summer of 2005, visits were made to companies to discuss hiring of lower division students. Early in the fall semester, presentations were made to all sections of the Introduction to Engineering course, and students completed an Engineering Internships Survey included as Appendix A. Students who had taken the introductory course the prior year, and were now taking sophomore coursework, were also contacted by email and encouraged to fill out the assessment and submit resumes. Collecting and analyzing student data to obtain a better idea of available skill sets facilitated matching students to employer requirements. It also provided a means to describe student ability to employers and convince them that students could bring added value to the company. The following is an example of data obtained from the 97 surveys completed:

\section{Interest in Internships:}

- 97 respondents: 77 freshmen and 20 sophomores

- $88 \%$ were interested in obtaining an internship

- $5 \%$ were uncertain

- $3 \%$ were not interested now because they work full-time

\section{Preference of type of Internship:}

- $66 \%$ had no preference toward research assistantship or industry internship

- $20 \%$ preferred working for a company

- $1 \%$ preferred a research assistantship

\section{Experience:}

- $73 \%$ have customer service experience

- 70\% have "hands on" skills including machining, computer assembly, troubleshooting, electronic and mechanical repair, soldering, welding, and construction

- $21 \%$ have project management or leadership experience

- $15 \%$ have at least functional knowledge of either 2D or 3D CAD systems

Communicating directly with employers regarding their internship requirements and expectations facilitates opportunities for lower division students. For example, one company emailed the College of Engineering an internship job description that was well beyond the experience of even juniors or seniors. Communicating directly with the company revealed that the internship description had been taken from an experienced engineering position, and that the actual expectation was a basic familiarity with SolidWorks, a freshman level mechanical engineering course, and an interest in design.

Identifying a company that was historically receptive to hiring sophomores proved beneficial. One company that was contacted had employed two sophomore students in the past. After mentoring the interns for three years, upon graduation, they hired the graduates and had experienced project managers that were very familiar with the company work environment and culture. This example of success was used to help persuade other companies to consider mentoring a lower division student.

For both research assistantships and industry internships, locating a mentor that is willing to supervise a lower-division student is critical. It is crucial for managers to realize that the freshman or sophomore student can fill the need for the more basic elements of engineering tasks while receiving out of the classroom experience. The ideal mentor also realizes that there is an 
altruistic aspect to hiring an intern, that the student can not be simply considered "cheap" labor, and that the student should be assigned tasks with reasonable expectations. The following skill sets and attributes are commonly sought by employers when hiring interns.

- A desire and willingness to learn

- Strong work ethic

- Familiarity with 2D CAD or 3D solid modeling software

- Customer service experience

- Basic mechanical 'hands on' experience including machining, soldering, construction experience

- Work experience that includes supervisory experience

- Basic circuits knowledge

Although a willingness to learn and a strong work ethic are difficult to quantify, a large percentage of our freshmen and sophomores surveyed have many of the skills and experience employers are seeking.

The goal for the academic year 2005-06 is to place 15 lower division interns in industry, with a goal of 25 for the following year. To date, six sophomores and two freshmen have been placed in industry internships as displayed in Table 2.

\begin{tabular}{|l|l|l|}
\hline $\begin{array}{c}\text { Intern's } \\
\text { Major }\end{array}$ & \multicolumn{1}{|c|}{ Type of Company } & \multicolumn{1}{c|}{ Tasks } \\
\hline ME & $\begin{array}{l}\text { Semiconductor precision } \\
\text { equipment manufacturer }\end{array}$ & $\begin{array}{l}\text { Researching materials selection and contacting } \\
\text { vendors }\end{array}$ \\
\hline ME & $\begin{array}{l}\text { Ventilation equipment } \\
\text { manufacturer }\end{array}$ & $\begin{array}{l}\text { Participating in the implementation of lean } \\
\text { manufacturing and some tooling re-design }\end{array}$ \\
\hline EE & Semiconductor & Conducting tests on digital devices \\
\hline EE & Telemetry and monitoring & $\begin{array}{l}\text { Developing and testing prototype boards } \\
\text { Entering schematics in company software }\end{array}$ \\
\hline CE & Structural engineering & Sizing beams using a software tool \\
\hline CE & Surveying and civil engineering & CAD drawings \\
\hline $2 \mathrm{CEs}$ & Highway district & Collect and input mapping and monitoring data \\
\hline
\end{tabular}

Table 2. Placement of lower division interns in industry as of early 2006.

The lower division industry internship program serves as a synergistic relationship building tool. Taking the time to approach companies, and meeting with engineering managers and company presidents on site allows companies to learn about the College of Engineering. These relationships open doors to explain projects and research facilities at the College. Progressive interaction with companies offers them opportunities to partner with the university leading to open dialogue. It is truly a "Win-Win-Win" relationship in that the students and College ultimately benefit due to enhanced learning experiences, increased sources of senior design projects, possible student employment, and an opportunity for employers to preview potential future professional employees. 


\section{Program Future}

The university Career Center is planning to implement a "soft-skills" seminar during the 2006-07 academic year. All lower division students wishing to participate in the engineering internship program will be encouraged to attend. For the academic year 2006-07, a forum is in the preliminary design stage in which students who have interned and employers could meet and share work experiences. Mandatory enrollment in the Introduction to Engineering course prior to an industry internship is being considered. The course introduces basic engineering concepts, and discusses resumes, internships, professionalism, and engineering ethics. Students do not take the Technical Communication course, which covers resume writing in depth, until late in the sophomore year, so all lower division students are advised to meet with the internship coordinator for resume assistance.

\section{Evaluation and Assessment}

To assess program effectiveness, students both in the College of Engineering research laboratories and industry internships will be asked to fill out a survey to reflect on their experience and describe basic tasks completed. Similarly, employers will be asked to complete brief reports about student performance. Student and employer feedback will be invaluable to carefully improve the program. Data will be gathered at the end of each year including student academic courseload, GPA and number of internship hours to identify any correlations between academic success and the internship experience. Other factors such as student demographics and distance commuted to the worksite will be collected to help evaluate parameters that affect student success and their internship experience. The ultimate goal of the program, student retention, will be tracked by student re-enrollment in engineering.

\section{Summary}

Undergraduate education in research universities requires renewed emphasis on a point strongly made by John Dewey almost a century ago: learning is based on discovery guided by mentoring rather than on the transmission of information. Inherent in inquiry-based learning is an element of reciprocity: faculty can learn from students as students are learning from faculty. ${ }^{5}$

Boise State University is a metropolitan university, with a relatively high percentage of nontraditional students $(46 \%)$. Non-traditional students are at higher risk of not completing their degree, and typically need more income due to family obligations. However, they often have a broader range of skill sets and experience as compared to traditional students enrolling directly out of high school. Hence, non-traditional can be more marketable to employers than traditional students. Therefore, an industry internship program that includes lower division students can be extremely helpful to the non-traditional student, and should impact a significant number of our engineering undergraduates.

With the exception of some non-traditional students, college research assistantships are more appropriate to first-year students than industry internships. Time spent off-campus including commuting may be distracting to first year students attempting to acclimate to the rigors of university academics. Freshmen in research laboratories receive valuable mentoring from upper 
division and graduate researchers and faculty. Industry prefers at least a sophomore to know the student is serious and staying in engineering; one of the primary motives of a company to hire an intern is the possibility the student will become a permanent employee after graduation. Hence, summer post-freshman year would be the most ideal time to start an industry internship. For both research and industry, it is important to identify mentors that set appropriate expectations to avoid an experience that could be negative for both parties.

Placement of lower division students in industry requires a relatively high level of involvement by college professional staff. However, this effort achieves other benefits beyond internships to the college and the students including increased awareness of the engineering program with industry, senior design projects, "friend raising" that enhances development efforts, and research collaboration opportunities.

\section{Bibliography}

${ }^{1}$ Belchier, Marcia J., PhD., "Why Fall 2003 Freshmen Left Boise State University and Whether They Plan to Return," Research Report 2005-02, Boise State University, January 2005, pp 1-2.

${ }^{2}$ Zydney, A., J. Bennett, A. Shahid, and K. Bauer. "Impact of Undergraduate Research Experience in Engineering, Journal of Engineering Education," April 2002.

${ }^{3}$ Blair, B., M. Millea, and J. Hammer. "The Impact of Cooperative Education on Academic Performance and Compensation of Engineering Majors,” Journal of Engineering Education, October 2004.

${ }^{4}$ Armstrong, David J., "Non-Traditional Students Face Barriers to Degree Completion," Florida Department of Education, June 2003.

${ }^{5}$ The Boyer Commission on Education Undergraduates in the Research University, "Reinventing Undergraduate Education: A Blueprint for America's Research Universities," 1998.

\section{Appendix A}

\section{Engineering Internships Survey}

Fall 2005

Name
Email address:
Phone (optional)
Major
Class Standing in Engineering (Fresh, Soph, Jr, Sr)
Math and Physics courses completed:

Engineering courses completed: 
Just because you may not answer yes to many of these skill sets, DO NOT ASSUME that you are not qualified to be employed as a student intern! High priorities to employers are a willingness to learn, intelligence, positive attitude, and a good work ethic.

All of the internship positions are paid.

Are you interested in an internship position? Y N

Would you prefer to work as a university employee (i.e., research lab), or for a company, or no preference?

Would you prefer full-time summer only? Y N

Would you like to work part-time during the school year? $\mathrm{Y} N$

If so, what range of hours would you prefer to work per week?

Would you be interested in occasional technical jobs that were part-time and short term? Y N

Would you be interested in a job that included field work versus office work? $\mathrm{Y} N$

Would you be interested in a semester 'co-op' program, where you work in an internship position full-time for a semester? Y N

Skills: (For 1 through 5 responses)

$1=$ none $\quad 2=$ limited $3=$ functional knowledge $\quad 4=\operatorname{good} \quad 5=$ expert

Do you have experience with any of the following?

Two dimensional CAD software? AutoCad, Microstation, or other?

$\begin{array}{llllll}\text { What is your experience level? } & 1 & 2 & 3 & 4 & 5\end{array}$

Three dimensional CAD software? SolidWorks, AutoCad 3-D, or other?

$\begin{array}{llllll}\text { What is your experience level? } & 1 & 2 & 3 & 4 & 5\end{array}$

Programming: C, C++, Visual Basic, JAVA, other.

What is your experience level?

\begin{tabular}{lllll}
\hline 1 & 2 & 3 & 4 & 5
\end{tabular}

Platforms: DOS, UNIX, LINUX, other. What is your experience level?

\begin{tabular}{lllll}
\hline 1 & 2 & 3 & 4 & 5
\end{tabular}

Programming or operation of CNC machinery? What is your experience level?

\begin{tabular}{lllll}
\hline 1 & 2 & 3 & 4 & 5
\end{tabular}

Microsoft office applications- experience level:

$\begin{array}{lccccc}\text { Excel } & 1 & 2 & 3 & 4 & 5 \\ \text { Access } & 1 & 2 & 3 & 4 & 5 \\ \text { PowerPoint } & 1 & 2 & 3 & 4 & 5 \\ \text { Word } & 1 & 2 & 3 & 4 & 5\end{array}$

Other applications such as MathCad, LabView, database management software, or other and experience level for each:

How would you rate your writing ability?

How would you rate your speaking ability?

$\begin{array}{lllll}1 & 2 & 3 & 4 & 5 \\ 1 & 2 & 3 & 4 & 5\end{array}$




\section{Work experience}

Have you worked in customer service dealing directly with customers in person or on the phone? Y N

Do you have any kind of project management experience, i.e., volunteer team projects, construction projects? Please list examples:

"Hands on" experience, for example, mechanical hardware (repairs, 'tinkering'), machining, soldering, 'wetlab' experience, computer hardware, soils testing, etc. Please list any examples:

List any skills or work experience that were not listed above:

\section{List any interests outside of engineering:}

There are many specialties within engineering (far more than are listed here).

Circle the areas that you think might interest you, or please list any others if you wish:

Consulting firms, building facilities, HVAC (heating, ventilation and cooling), power, semiconductor industry, digital devices, controls, manufacturing, structural, geotechnical, environmental, transportation, roadways, bridges, mechanical design, test, research and development. 